\title{
SENSORY ANALYSIS OF COFFEE DRIED WITH AND WITHOUT STIRRING
}

\author{
Bruno Batista Ribeiro' ${ }^{1}$, Francisco Mickael de Medeiros Câmara², Antônio Nazareno Guimarães Mendes³, \\ Virgílio Anastácio da Silva ${ }^{4}$, Fernanda Faria Montanari ${ }^{5}$
}

(Received: May 22, 2018; accepted: September 19, 2018)

\begin{abstract}
The production of quality coffees, with different sensory characteristics, is strongly related to drying techniques. Experiments were carried out on coffee fruits, with the presence and absence of the fruit turnover process during drying, using Catuaí Vermelho 144 coffee fruits, from the Cerrado Mineiro, processed dry and wet. The treatments consisted of natural coffee, natural green coffee, pulped coffee and semi-washed coffee fruits. They were carried out in a completely randomized design, with 4 post-harvest processes, 2 types of drying (with or without Stirring) and 3 replicates, totaling 24 plots. Natural green coffee and natural coffees were more responsive in the final scores, when not stirred during the drying process, unlike the coffees obtained by wet processing. Peeled coffees obtained the highest scores for the attributes, regardless of the adoption or not of stirring during the drying process. It was possible to obtain scores above 80 points by the SCAA protocol, without stirring the coffee.
\end{abstract}

Index terms: Sensory analysis, Coffea arabica L., drying, SCAA, quality.

\section{ANALISE SENSORIAL DE CAFÉS SECADOS COM E SEM REVOLVIMENTO}

RESUMO: A produção de cafés de qualidade, com características sensoriais diferenciadas, está fortemente relacionada com técnicas de secagem. Foram realizados experimentos de secagem de frutos de cafés, com a presença e ausência do processo de revolvimentos de frutos durante a secagem, utilizando frutos de café da cultivar 'Catuaí Vermelho 144', proveniente da região do Cerrado Mineiro, processados por via seca e via úmida. Os tratamentos contaram com frutos de cereja natural, verde natural, cereja descascado e cereja desmucilado os quais passaram por secagem conduzida em terreiro de concreto. Utilizou-se o delineamento inteiramente casualizado, com 4 processos pós-colheita, 2 tipos de secagem (com ou sem revolvimento) e 3 repetições, totalizando 24 parcelas. Os cafés, verde natural e cereja natural foram mais responsivos nas notas finais, quando não revolvidos durante o processo de secagem, diferentemente dos cafés obtidos pelo processamento via úmida. Os cafés descascados obtiveram as maiores notas para os atributos, independentemente da adoção ou não do revolvimento durante o processo de secagem. Foi possível obter notas acima de 80 pontos pelo protocolo SCAA, sem o procedimento de revolvimento do café.

Termos para indexação: Análise sensorial, Coffea arabica L., secagem, SCAA, qualidade.

\section{INTRODUCTION}

Coffee farming is crucial to the economy of many countries as it generates millions of jobs in various parts of the world (HUGHES et al., 2014). The increasing demand for coffees with different qualitative characteristics has presented a scenario of innovations in technologies and production techniques for coffee cultivation.

Drying is the oldest technique for preserving food and agricultural products (MAISNAM et al., 2017), and it is the process wherein moisture is removed from the food material as a result of concurrent heat and mass transfer (MARQUES et al., 2008; SONTAKKE; SALVE, 2015). Before drying, coffee fruits can be processed by two methods: dry or dry (RATTAN et al., 2015). During the drying of fruits, the resulting decrease in water potential induces several metabolic responses (KLEINWÄCHTER; SELMAR, 2009) and consequently, changes in the composition of the substances present, besides coffee sensory quality (JÖ̈T, et al., 2010).
According to Palacin et al. (2009), the encouragement for the development of new concepts to improve the unit operations of preprocessing and processing of fruits and grains is evident, in which hygiene and care to reduce, or even reduce mechanical and thermal damage, have become essential.

Thus, drying is a key stage in coffee postharvest and should be started soon after harvest to rapidly reduce the high water content of the husk, pulp and mucilage and avoid fermentation, which may impair coffee quality; in addition, the operation is considered critical for providing thermal stress, development of fungi, addition of smoke odors, and other contaminants in fruits or grains (ABRAÃO et al., 2010; PALACIN et al., 2009; RESENDE et al., 2009). However, the best drying method is the one that meets the characteristics of each region, producer and desired quality standard, aiming at profitability and consumer satisfaction (SAATH, 2010).

1,2,3,4,5 Universidade Federal de Lavras/UFLA - Departamento de Agricultura/DAG - Cx. P. 3037 - 37.200-000 - Lavras - MGbrunoberibeiro@hotmail.com, mickaelmedeiros@hotmail.com,naza@dag.ufla.br, virgílio@dag.ufla.br, fernanda_montanari@hotmail.com 
Sensory analysis has the ability to give a scientific evaluation and a quantitative measure to the appearance, flavor and texture of a food product, and it is essential to define performance standards and evaluate the progress of the implemented process (IANNARIO et al., 2012).

The stirring rate in coffee drying process is not treated in literature. There is a lack of knowledge about its benefits or damage in coffee sensory characteristics. It is important to emphasize that the absence of stirring reduces costs, once you diminish labor to do this activity.

In this context, the objective in this research was to identify the sensory attributes by the protocol of the Specialty Coffee Association of America (SCAA) for coffees obtained by the wet and dry process, dried with and without stirring.

\section{MATERIAL AND METHODS}

The experiment was carried out in Minas Gerais in 2016, in the region of the Cerrado Mineiro, municipality of Coromandel, in a private coffee property. 'Catuaí Vermelho 144' coffee fruits were processed dry and wet. Treatments, as well as the control of natural coffee fruits, natural green coffees, pulped coffee, semi-washed coffee underwent drying process.

Initially it was delimited in the border space in the field, respecting three rows started after the "carrier way" and the three plants in the row to start harvest. The plants were demolished by an automotive harvester until a total of 1500 liters of coffee fruits, and a selection was made, removing remaining green fruits, which composed the natural green plot, besides hydraulic separation of drier fruits in a washer. Of the remaining coffee from the washer, part passed by the parchment peeler and part by the peeler and by the demister. It is worth mentioning that the tests were performed on days of full sun.

The experiment was carried out in a completely randomized experimental design (DIC) with 4 processes (natural coffee, natural green coffee, peeled parchment, semi-washed coffee, 2 types of drying (with and without stirring) and 3 replicates, totaling 24 plots with 30 liters each.

The drying procedures for each treatment are described below:

\section{Coffee beans dried with stirring process Natural coffee and Natural Green Coffee}

The coffees were scattered in a layer $3 \mathrm{~cm}$ high, stirred 8 times a day and, after being "half- dry", they were surrounded and covered with cloths + plastic canvas. The next day, the cloths along with the tarpaulins were removed after the haze disappeared, and the coffee was again spread and stirred 8 times, until the samples reached $11.5 \%$ moisture. The drying time of the samples in cement yard in the region and conditions under study was between 16 and 18 days.

\section{Pulped coffee and Semi-washed Coffee}

The coffees were scattered in a layer $3 \mathrm{~cm}$ high, tilted 12 times a day and, after being "halfdry", they were layered and covered with cloths + plastic canvas. The next day, the cloths along with the tarpaulins were removed after the haze disappeared, and the coffee was again spread and stirred 12 times, until the samples reached $11.5 \%$ moisture. The drying time of the samples in cement yard in the region and conditions under study was between 9 and 12 days.

\section{Coffee beans dried without stirring process}

\section{Natural coffee}

In the first days of drying in a cement yard, the coffees were scattered in thin layers (fruit to fruit) allowing the rapid removal of surface water and dehydration of the remaining mucilage, during 4 days. After the "browning of the bark", the drying layer was passed to $50 \%$ of the yard space. After drying the remaining water of the bark (as the fruits stop melting in the hand), the drying layer went to $25 \%$ of the yard space and was kept for 1 day in full sun. Subsequently, a sombrite screen with $50 \%$ brightness was placed on the coffee samples, and cloths were placed together with the plastic canvas on the sombrite, remaining all day long. By the next day, the cloths along with the tarpaulins were removed after the haze had disappeared, and the sombrite remained. This procedure was repeated until the samples reached $11.5 \%$ moisture. The drying time of the samples in cement yard, in the region and conditions under study was between 15 and 17 days.

\section{Natural Green Coffee}

In the first 2 days of drying of the green coffees the fruits were scattered in the cement yard in thin layers "fruit to fruit", allowing the appearance of dark spots on the bark. After these darkening points, the drying layer was passed to $50 \%$ of the yard space and maintained, for 2 days in full sun. After the 2 days, the layer went to $25 \%$ of the space of the yard and was maintained, 
for 2 days in full sun. Subsequently, a sombrite screen with $50 \%$ brightness was placed on the coffee samples, and cloths were placed together with the plastic canvas on the sombrite, remaining all day long. By the next day, the cloths along with the tarps were removed after the fog had disappeared, but the sombrite was kept. This procedure was repeated until the samples reached $11.5 \%$ moisture. The drying time of the samples in cement yard in the region and conditions under study was between 17 and 20 days.

\section{Pulped coffee}

In the early days of drying, the coffees were scattered in thin layers, "seed to seed" during drying in cement yard, allowing the rapid removal of surface water and dehydration of the remaining mucilage, during 2 days. After drying the mucilage, the drying layer was passed to $50 \%$ of the yard space and maintained for 2 days in full sun. After the 2 days, the layer went to $25 \%$ of the yard space, for 1 day in full sun. Subsequently, a sombrite screen with $50 \%$ brightness was placed on the coffee samples, and cloths were placed together with the plastic canvas on the sombrite, remaining all day long. By the next day, the cloths along with the tarps were removed after the fog had disappeared, and the sombrite was kept. This procedure was followed until the samples reached $11.5 \%$ moisture. The drying time of the samples in cement yard in the region and conditions under study was between 9 and 10 days.

\section{Semi-washed Coffee}

On the first day, the coffees were scattered in thin layers, "seed to seed" during drying in cement yard, allowing the rapid removal of surface water and dehydration of the remaining mucilage. After removal of the surface water and dewatering of the mucilage, during 1 day, the drying layer was passed to $50 \%$ of the yard space and kept for 1 day in full sun. After 1 day, the layer went to $25 \%$ of the yard space, for 1 day in full sunlight. Subsequently, a sombrite screen with $50 \%$ brightness was placed on the coffee samples in the hottest hours of the day, remaining all day long. By the next day, the cloths along with the tarpaulins were removed after the haze had disappeared, and the sombrite remained. This procedure was repeated until the samples reached $11.5 \%$ moisture. The drying time of the samples in cement yard in the region and conditions under study was between 9 and 10 days.
In the drying treatments of coffees without stirring, sombrites with graduation of $50 \%$ were used in order to minimize the direct incidence of the sunlight, which would damage the appearance of the grains, causing stains. This sombrite was added on the coffee, at different times according to the processes adopted.

\section{Sensory analysis protocol}

The sensory analyses were performed by two qualified and accredited panelists for the evaluation of special coffees (Q-Graders), using the methodology proposed by the Special Coffees Association of America - SCAA (LINGLE, 2011).

100 grams of each sample were roasted in a Probat TP2-Leogap roaster, in a 24 hour interval, before sensory analysis, with a coloring profile between \#58 for roasted grain and \#63 for roasted and ground grain, as verified by the equipment Mbasic Agtron. The roasting time was monitored, respecting the interval of 8 to 12 minutes, with the average roasting time between samples of 9 minutes and 15 seconds. Milling was standardized in a Guatemala - Mahlkönig mill, with an average texture of $70 \%$ of the powder passed through a 20 mesh sieve. The mineral water, used for infusion, was boiled at a temperature of $93^{\circ} \mathrm{C}$ \pm 1 . For each sample, five cups of $5.5 \% \mathrm{~m} / \mathrm{v}$ (roasted and ground coffee/water) were prepared for the sensory analysis procedure. All testers underwent calibrations prior to sensory analysis. The environment and location of the tastings were prepared for noise reduction, odor elimination and careful standardization for the evaluation of the treatments with quality levels with intervals of 0.25 points.

The following sensory attributes were evaluated: Aroma; Flavor; Finalization; Body; Acidity; Balance (acidity and body); Uniformity between Cups; Absence of defects; Sweetness and Global Impression. The sum of the scores obtained in the attributes resulted in the final scores.

\section{Histochemical analysis}

The bean samples were submerged in distilled water for four days and kept at room temperature. The sections for histochemical reactions, obtained by hand-free cutting using a stainless-steel blade, were treated for 3 minutes with the reagent Sudan IV in $80 \%$ ethanolic solution for the visualization of lipids, (JENSEN, 1962) with modifications (GOULART et al., 2007). The plank assembly was performed in the Corel Draw software. 


\section{Experimental Analysis}

Statistical analyses were performed using the Sisvar software (FERREIRA, 2011), using the Tukey test at $5 \%$ probability, the PCA analysis were performed using the PAST3 software (HAMMER et al., 2001).

\section{RESULTS AND DISCUSSION}

Through analysis of variance it was verified that there was an interaction between processes and treatments used for the analyzed variables, except for uniformity and clean cup. There was an isolated effect of process type only for sweetness.

For aroma and flavor, it was verified that the best treatments were for pulped coffee, with averages of 7.58 and 7.54 (with stirring) and 7.75 and 7.42 (without stirring), respectively. It is noteworthy that there was no difference between the two processes (with or without stirring) for pulped coffee. Semi-washed coffee had lower mean values when compared to the pulped coffee type, but only differed significantly in aroma, when the process without stirring was adopted (Table 1). For natural coffee and natural green coffee processing, the absence of stirring resulted in higher averages when compared to the stirring process.

These results might be related with a thinner layer of coffee beans arranged for drying, since drying without stirring needs a lesser mass of coffee to be dried by sunlight temperature and air, promoting an evenly moisture removal. Once the drying procedure goes on, it is necessary fold the layers and using the sombrite, to avoid excessive moisture removal and luminosity, preventing stains on the coffee beans.

This procedure initially has a high moisture removal rate, however, with the folds of layers and sun protection (sombrite), the rate decreases, preserving the lipid fraction. Lipids in coffee serve as carriers for flavors and for fat-soluble vitamins and contribute to texture and mouthfeel (RIBEIRO et al., 2009)

According to Manzocco and Lagazio (2009), any changes in composition of lipids may contribute to a loss of sensory quality of coffee beverages. Lipids might be hydrolyzed enzymatically or chemically and the rate at which these reactions occur depends on environmental and technological aspects, as well as availability of oxygen, moisture, temperature, and packaging material.
Aroma and flavor arise from quality, intensity and complexity of all the attributes found in the coffee beverage, consequently, it strongly influences the panelist's note, and it is one of the most important requirements for beverage quality (KNYSAK, 2017).

According to Tables 2 and 3 , it is verified that pulped coffee had the highest mean values for the variables finalization, acidity, body and balance, with values of $7.33,7.54,7.42$ and 7.42 (with stirring) and 7.29, 7.33, 7.42 and 7.33 (without stirring), respectively. Although once again the semi-washed coffee had smaller averages than pulped coffee, they only differ statistically in the variables body, with stirring, and in balance, both with and without stirring. For both natural coffees, the absence of stirring resulted in higher averages when compared to the process with stirring.

Body is recognized to be one of the most important sensory characteristics determining the quality of coffee beverages, high scores correspond to the richness of aroma and increased viscosity and density of beverages (NAVARINI et al., 2004), it is often related to the total solids and occasionally also linked to fat or fatty acid content (GLOESS et al., 2013) and results to body may be correlated with better aroma and flavor results, once pulped and semi-washed coffees had the higher averages.

Acidity contributes to the liveliness of a coffee, with the perception of sweetness (SCAA, 2008). Furthermore, for sustained sensation at the end of a sip, the finishing should be well balanced between the aroma, acidity, bitterness and astringency (GLOESS et al., 2013). Overall, semi-washed and pulped coffees obtained great results for these variables.

It is important to note that natural coffee without stirring had higher means compared to stirring, this could be associated to drying kinetics, where thick layers where the coffee beans are disposed in drying with stirring, reduces water removal and homogeneity. The increase in temperature reduces the viscosity of the water, directly influencing the resistance of the fluid to the flow; the decrease of the viscosity facilitates the diffusion of the water molecules in the capillaries of the product (CORREAA et al., 2010). In other words, thick layers and holding the peel and pulp in the coffee beans, gives conditions to fermentation and/or enhance in loss of quality. 
TABLE 1 - Averages of aroma and flavor of coffee drinks according to treatments and drying processes*.

\begin{tabular}{ccccc}
\hline \multirow{2}{*}{ TREATMENTS } & \multicolumn{4}{c}{ DRYING PROCESSES } \\
\cline { 2 - 5 } & $\begin{array}{c}\text { WITH } \\
\text { STIRRING }\end{array}$ & $\begin{array}{c}\text { WITHOUT } \\
\text { STIRRING }\end{array}$ & WITH STIRRING & $\begin{array}{c}\text { WITHOUT } \\
\text { STIRRING }\end{array}$ \\
\cline { 2 - 5 } AROMA & \multicolumn{2}{c}{ FLAVOR } \\
\hline NAT. GREEN COFFEE & $6.04 \mathrm{Cb}$ & $6.45 \mathrm{Ca}$ & $6.04 \mathrm{Cb}$ & $6.50 \mathrm{Ca}$ \\
NAT. COFFEE & $7.13 \mathrm{Bb}$ & $7.70 \mathrm{Aa}$ & $7.04 \mathrm{Bb}$ & $7.20 \mathrm{Ba}$ \\
PULPED COFFEE & $7.58 \mathrm{Aa}$ & $7.75 \mathrm{Aa}$ & $7.54 \mathrm{Aa}$ & $7.42 \mathrm{Aa}$ \\
SEMI-WASHED COFFEE & $7.42 \mathrm{Aa}$ & $7.38 \mathrm{Ba}$ & $7.29 \mathrm{Aa}$ & $7.50 \mathrm{Aa}$ \\
\hline * Averages followed by the same letter, upper case in the column and lowercase in the row, do not differ by Tukey's \\
test (p<0.05).
\end{tabular}

TABLE 2 - Averages of finishing and acidity of coffee drinks according to treatments and drying processes*.

\begin{tabular}{ccccc}
\hline \multirow{2}{*}{ TREATMENTS } & \multicolumn{4}{c}{ DRYING PROCESSES } \\
\cline { 2 - 5 } & $\begin{array}{c}\text { WITH } \\
\text { STIRRING }\end{array}$ & WITHOUT STIRRING & WITH STIRRING WITHOUT STIRRING \\
\cline { 2 - 5 } FINISHING & \multicolumn{3}{c}{ ACIDITY } \\
\hline NAT. GREEN COFFEE & $6.00 \mathrm{Cb}$ & $6.25 \mathrm{Ca}$ & $6.04 \mathrm{Cb}$ & $6.37 \mathrm{Ca}$ \\
NATURAL COFFEE & $6.91 \mathrm{Bb}$ & $7.29 \mathrm{Aa}$ & $7.04 \mathrm{Bb}$ & $7.45 \mathrm{Aa}$ \\
PULPED COFFEE & $7.33 \mathrm{Aa}$ & $7.29 \mathrm{Aa}$ & $7.54 \mathrm{Aa}$ & $7.33 \mathrm{Aa}$ \\
SEMI-WASHED COFFEE & $7.16 \mathrm{Aa}$ & $7.12 \mathrm{Aa}$ & $7.29 \mathrm{Aa}$ & $7.25 \mathrm{Aa}$ \\
\hline *Averages followed by the same letter, upper case in the column and lowercase in the row, do not differ by Tukey's \\
test $(\mathrm{p}<0.05)$.
\end{tabular}

TABLE 3 - Averages of body and balance of coffee beverages according to treatments and drying processes*.

\begin{tabular}{|c|c|c|c|c|c|}
\hline \multirow{3}{*}{ TREATMENTS } & \multicolumn{5}{|c|}{ DRYING PROCESSES } \\
\hline & $\begin{array}{c}\text { WITH } \\
\text { STIRRING }\end{array}$ & \multicolumn{2}{|c|}{ WITHOUT STIRRING } & WITH STIRRING & WITHOUT STIRRING \\
\hline & \multicolumn{3}{|c|}{ BODY } & \multicolumn{2}{|c|}{ BALANCE } \\
\hline NAT. GREEN COFFEE & $6.00 \mathrm{Cb}$ & \multicolumn{2}{|c|}{$6.29 \mathrm{Ca}$} & $6.00 \mathrm{Db}$ & $6.25 \mathrm{Ca}$ \\
\hline NATURAL COFFEE & $6.92 \mathrm{Bb}$ & \multicolumn{2}{|c|}{$7.50 \mathrm{Aa}$} & $6.91 \mathrm{Cb}$ & \\
\hline PULPED COFFEE & $7.42 \mathrm{Aa}$ & \multicolumn{2}{|c|}{$7.42 \mathrm{Aa}$} & $7.42 \mathrm{Aa}$ & $7.33 \mathrm{Ab}$ \\
\hline SEMI-WASHED COFFEE & $7.13 \mathrm{Ba}$ & \multicolumn{2}{|c|}{$7.25 \mathrm{Aa}$} & $7.16 \mathrm{Ba}$ & $7.12 \mathrm{Ba}$ \\
\hline \multicolumn{6}{|c|}{$\begin{array}{l}\text { * Averages followed by the same letter, upper case in the column and lowercase in the row, do not differ by Tukey's } \\
\text { test }(p<0.05) \text {. }\end{array}$} \\
\hline \multicolumn{3}{|c|}{$\begin{array}{l}\text { Guimarães et al. (2002) reported that during } \\
\text { drying, some sugars may accumulate, and it is one } \\
\text { of the possible defense mechanisms against stress } \\
\text { caused by desiccation. The authors point out that } \\
\text { these sugars can be enhanced or reduced according } \\
\text { to the seed drying rate and/or environmental } \\
\text { conditions. Sugars are precursors of sweetness } \\
\text { and contribute to the body of the coffee beverage. }\end{array}$} & \multicolumn{3}{|c|}{$\begin{array}{l}\text { Except for general score with stirring not } \\
\text { differing from semi-washed coffee, general and final } \\
\text { scores of the beverages with pulped coffee were } \\
\text { higher to the other treatments, with averages of } 7.50 \\
\text { and } 82.29 \text { (with stirring) and } 7.46 \text { and } 82 \text { (without } \\
\text { stirring), respectively (Table 4). For natural coffee, } \\
\text { the average of the final scores was higher, due to } \\
\text { the absence of stirring in the drying process, when } \\
\text { compared to the adoption of stirring } 8 \text { times a day. }\end{array}$} \\
\hline
\end{tabular}


These results reveal no necessities of stirring coffee, which can assist producers in making decisions in post-harvest processes, reviewing the need for the requirement to constantly stir up lots of coffees.

It should be emphasized that the quality of specialty coffees is related to the intrinsic characteristics of the beans, showing chemical compounds which, after roasting, will provide aroma, flavor, acidity, sweetness and bitterness to the beverage, in addition to the synthesis, accumulation and degradation of chemical compounds of the raw coffee bean, considered flavor precursors of the beverage (TAVEIRA et al., 2014).

Researches with specialty coffees is still scarce due to the small production of quality coffee and the lack of researchers working in this specific field. However, some studies have been carried out to verify the influence of pre and postharvest management on the quality of specialty coffees (ALVES et al., 2013; KREUML et al., 2013). Among the post-harvest stages, drying has been one of the main targets of studies (ALVES et al., 2017; SIQUEIRA et al., 2016), since it is known that this technique has a great influence on the final quality of agricultural products.

For sweetness stirring effect was not verified, there was statistical difference only among treatments. Semi-washed coffee, pulped coffee and natural coffee had better grade means 9.92, 9.88 and 9.87, respectively, where green coffee was inferior to the other treatments.

Figure 1 shows the two principal components, accounting for $99.48 \%$ of data variability and the principal component 1 holds the major variance, $(\mathrm{PC} 1=98.964 \%$ and $\mathrm{PC} 2=0.516 \%$ ), it may perfectly be used to represent the set of the variables measured for the tested treatments, since it incorporates over $80 \%$ of the variance.
In this type of data analysis, it is possible to group the treatments that reveal similarity among variables. To obtain coffee beverage with better aroma, flavor, body and balance the best treatments are pulped coffee with or without stirring and natural coffee with stirring. Great acidity and finishing can be reached in the beverages when semi-washed coffees are treated or not with stirring and in natural coffee stirring is made. Natural green coffee had the worst results to all variables, independent of the usage of stirring.

These results lead to a new possibility of making different beverages, depending on market trends and costumer's acceptability. Overall, it is possible to obtain high-quality coffee beverages without the stirring process, thus decreasing the manpower required for this operation.

It is worth to emphasize that semi-washed and pulped coffees were better than natural green and natural coffees. Green coffee was expected to present these lower results, once the fruits did not reach the physiological maturity. For natural coffee, the drying process may be linked to the lower results. According to Santos et al. (2009), natural coffee beans are exposed to higher initial water contents, which may favor the occurrence of undesirable fermentation, depreciating the product.

Wet processing could bring more benefits to beverage quality, Joët et al. (2010), noted that significant metabolism occurs during wet processing which could lead to increase of chemical substances such lipids. In this sense, an increase in lipid content plus effects from no using stirring procedure may lead to a better coffee beans quality.

TABLE 4 - Averages of the general and final scores of coffee beverages according to treatments and drying processes*.

\begin{tabular}{ccccc}
\hline \multirow{2}{*}{ TREATMENTS } & \multicolumn{4}{c}{ DRYING PROCESSES } \\
\cline { 2 - 5 } & $\begin{array}{c}\text { WITH } \\
\text { STIRRING }\end{array}$ & $\begin{array}{c}\text { WITHOUT } \\
\text { STIRRING }\end{array}$ & WITH STIRRING & $\begin{array}{c}\text { WITHOUT } \\
\text { STIRRING }\end{array}$ \\
\cline { 2 - 5 } & \multicolumn{2}{c}{ GENERAL SCORE } & \multicolumn{2}{c}{ FINAL SCORE } \\
\hline NAT. GREEN COFFEE & $6.13 \mathrm{Ca}$ & $6.38 \mathrm{Ca}$ & $62.25 \mathrm{Db}$ & $64.50 \mathrm{Ca}$ \\
NATURAL COFFEE & $6.96 \mathrm{Cb}$ & $7.54 \mathrm{Aa}$ & $78.87 \mathrm{Cb}$ & $82.45 \mathrm{Aa}$ \\
PULPED COFFEE & $7.50 \mathrm{Aa}$ & $7.46 \mathrm{Aa}$ & $82.29 \mathrm{Aa}$ & $82.00 \mathrm{Aa}$ \\
SEMI-WASHED COFFEE & $7.25 \mathrm{Aa}$ & $7.13 \mathrm{Ba}$ & $80.75 \mathrm{Ba}$ & $80.45 \mathrm{Ba}$
\end{tabular}

*Averages followed by the same letter, upper case in the column and lowercase in the row, do not differ by Tukey's test $(\mathrm{p}<0.05)$. 


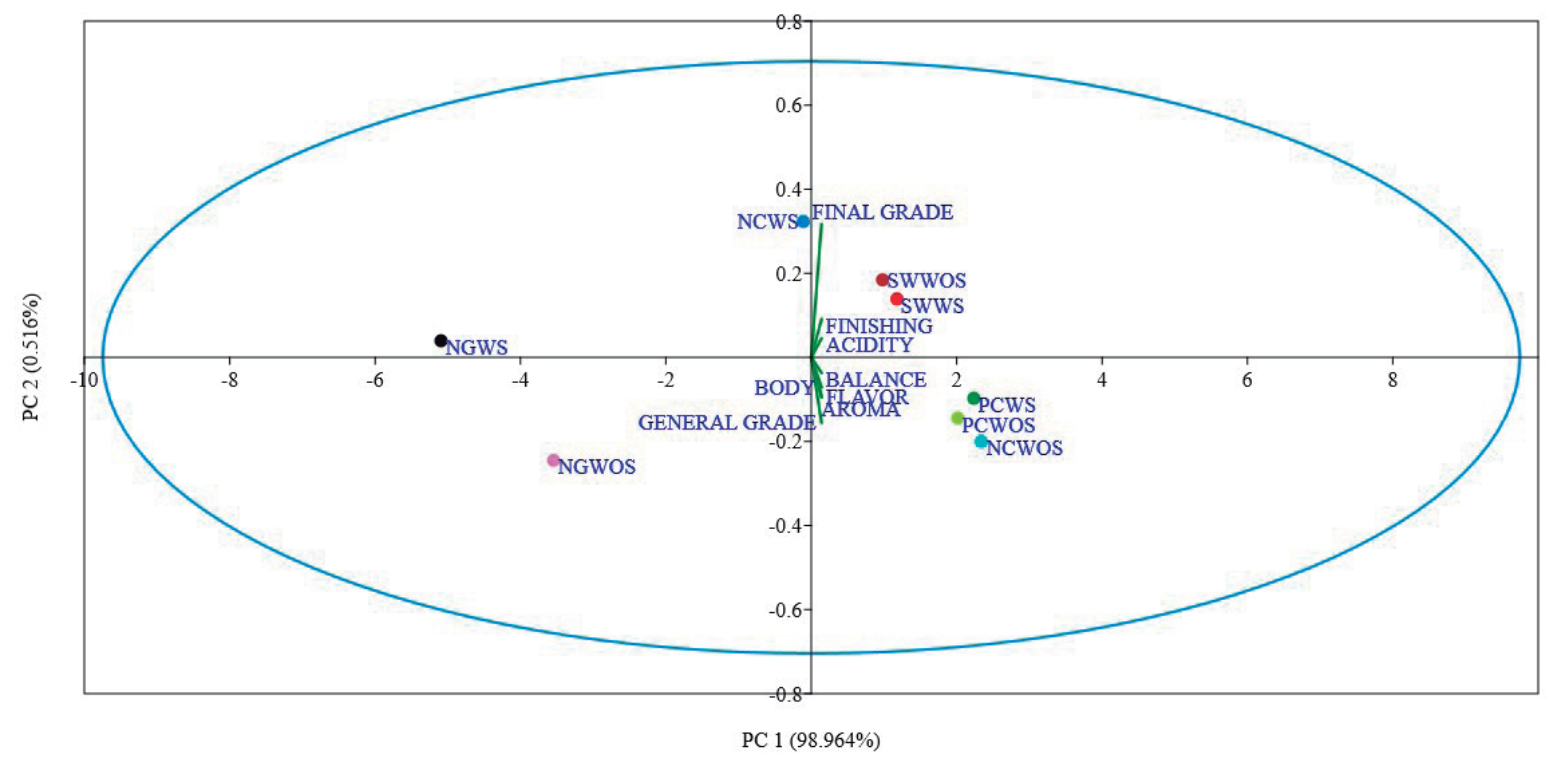

FIGURE 1 - Relationship between the two principal components of the treatments and drying processes variables. $\mathrm{NGWS}=$ natural green coffee with stirring, $\mathrm{NGWOS}=$ natural green coffee without stirring, $\mathrm{NCWS}=$ natural coffee with stirring, $\mathrm{NCWOS}=$ natural coffee without stirring, $\mathrm{PCWS}=$ pulped coffee with stirring, $\mathrm{PCWOS}=$ pulped coffee without stirring, SWWS= semi-washed coffee with stirring, SWWOS= semi-washed coffee without stirring.

Figure 2 presents the histochemical sections made in the coffee beans submitted to the different post-harvest processes, dried in the presence and absence of stirring. Coffees without the stirring procedure during drying had visually higher lipid concentrations in the peripheral regions of the beans as can be verified by arrows. Probably drying coffee without stirring promotes a better lipid content integrity, which implies better aroma and flavor on beverage.

The agronomical management made during the fruit production must preserve the integrity of the cell wall of the coffee beans and, consequently, collaborates with lipid organization (GOULART et al., 2007).

According to Goulart et al. (2007), better quality coffee shows a higher lipid concentration in the peripheral region of the beans, with well defined globular lipid bodies within the protoplasts. With the loss of beverage quality, the lipids are homogeneously distributed in the coffee beans tissues. The preservation of the integrity of these structures is important, since the oils besides the retainers of aromatic components act together with other compounds in the formation and perception of the beverage body (SCAA, 2008).

It is worth mentioning that, given the influence of the drying process in the post-harvest phase of coffee, and considering that the price paid for this product is directly proportional to its quality, this step is of great importance and must be performed in a technical way and to maintain the desirable characteristics of the product. In the case of special coffees drying, special attention must to be given, since the value paid for this product is well above that paid by the commodity coffee, thus, small flaws can lead to great losses. 

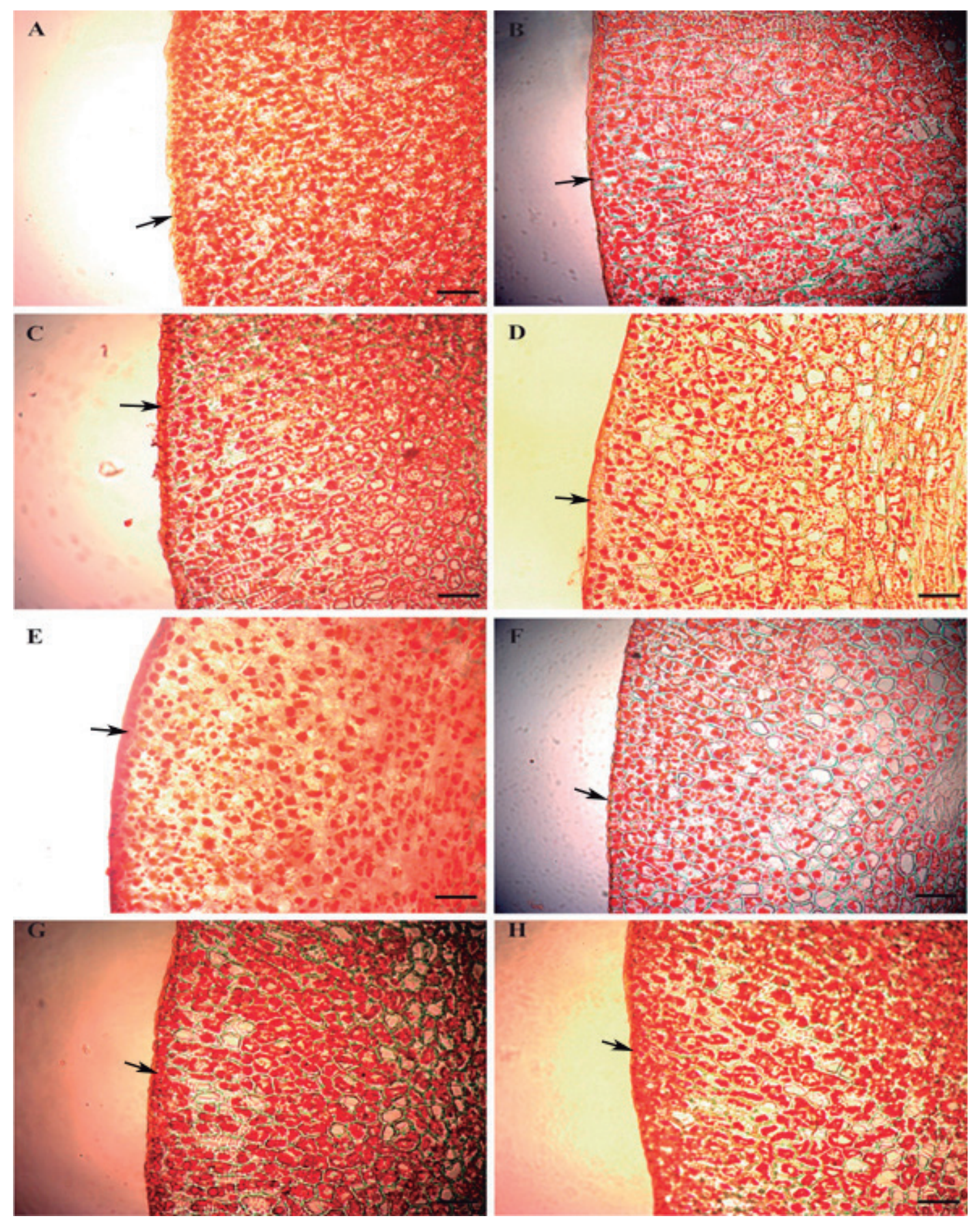

$\mathbf{B A R}=100 \mu \mathrm{m}$

FIGURE 2 - Sections of coffee beans: A) Natural coffee without stirring; B) Natural coffee with stirring; C) Pulped coffee without stirring; D) Pulped coffee with stirring; E) Semi-washed coffee without stirring; F) Semiwashed coffee with stirring; G) Natural green coffee without stirring; H) Natural green coffee with stirring 


\section{CONCLUSIONS}

Semi-washed and pulped coffees obtained higher scores between attributes and final scores. Coffees dried without stirring had scores above 80 points by the SCAA methodology and no differences compared to those stirred. Production of coffee without stirring can be adopted without loss in quality reducing cost in post-harvest coffee management.

\section{REFERENCES}

ABRAHÃO, S. A. et al. Compostos bioativos e atividade antioxidante do café (Coffea arabica L.). Ciência e Agrotecnologia, Lavras, v. 34, n. 2, p. 414420, Mar./Apr. 2010.

ALVES, G. P. et al. Physiological and sensorial quality of Arabica coffee subjected to different temperatures and drying airflows. Acta Scientiarum, Maringá, v. 39, n. 2, p. 225-233, Apr./June. 2017.

ALVES, G. P. et al. Drying kinetics of natural coffee for different temperatures and low relative humidity. Coffee Science, Lavras, v. 8, n. 2, p. 226-236, Apr./ June. 2013.

CORRÊA, P. C. et al. Modelagem matemática e determinação das propriedades termodinâmicas do café (Coffea arabica L.) durante o processo de secagem. Revista Ceres, Viçosa, v. 57, n. 5, p. 595-601, Sept./ Oct. 2010.

FERREIRA, D. F. Sisvar: A computer statistical analysis system. Ciência e Agrotecnologia, Lavras, v. 35, n. 6, p. 1039-1042, Nov./Dec. 2011.

GLOESS, A. N. et al. Comparison of nine common coffee extraction methods: instrumental and sensory analysis. European Food Research and Technology, v. 236, n. 4, p. 607-627, Apr. 2013.

GOULART, P. de F. P. et al. de. Aspectos histoquímicos e morfológicos de grãos de café de diferentes qualidades. Ciência Rural, Santa Maria, v. 37, n. 3, p. 662-666, May./June. 2007.

GUIMARÃES, R. M. et al. Tolerância à dessecação em sementes de cafeeiro (Coffea arabica L.). Ciência e Agrotecnologia, Lavras, v. 26, n. 1, p. 128-139, Jan./ Feb. 2002.

HAMMER, Ø.; HARPER, D. A. T.; RYAN, P. D. PAST: Paleontological statistics software package for education and data analysis. Palaeontologia Electronica, California, v. 4, n. 1, p. 1-9, 2001.
HUGHES, S. R. et al. Sustainable conversion of coffee and other crop wastes to biofuels and bioproducts using coupled biochemical and thermochemical processes in a multi-stage biorefinery concept. Applied Microbiology And Biotechnology, Berlin Heidelberg, v. 98, n. 20 , p. 8413-8431, Oct. 2014.

IANNARIO, M. et al. Sensory analysis in the food industry as a tool for marketing decisions. Advances In Data Analysis And Classification, Berlin Heidelberg, v. 6, n. 4, p. 303-321, Oct. 2012.

JENSEN, W. A. Botanical histochesmistry. San Francisco: Freeman, 1962. 408 p.

JOËT, T. et al. Influence of environmental factors, wet processing and their interactions on the biochemical composition of green Arabica coffee beans. Food Chemistry, London, v. 118, n. 3, p. 693-701, May. 2010.

KLEINWÄCHTER, M.; SELMAR, D. Influence of drying on the content of sugars in wet processed green Arabica coffees. Food Chemistry, Braunschweig, v. 119, n. 2, p. 500-504, Mar. 2010.

KNYSAK, D. Volatile compounds profiles in unroasted Coffea arabica and Coffea canephora beans from different countries. Food Science and Technology, Campinas, v. 37, n. 3, p. 444-448, July./Sept. 2017.

KREUML, M. T. L. et al. Changes in sensory quality characteristics of coffee during storage. Food Science \& Nutrition, v. 1, n. 4, p. 267-272, July./Aug. 2013.

LINGLE, T. R. The coffee cupper's handbook: systematic guide to the sensory evaluation of coffee's flavor. 4th ed. Long Beach: Specialty Coffee Association of America, 2011. 60 p.

MAISNAM, D. et al. Recents advances in conventional drying of foods. Journal of Food Technology Preservation, v. 1, n. 1, p. 25-34, 2016.

MARQUES, E. R. et al. Eficácia do teste de acidez graxa na avaliação da qualidade do café arábica (Coffea arabica L.) submetido a diferente períodos e temperaturas de secagem. Ciência e Agrotecnologia, Lavras, v. 32, n. 5, p. 1557-1562, Sept./Oct. 2008.

NAVARINI, L. et al. Espresso coffee beverage: classification of texture terms, Journal of Texture Studies, v. 35, n. 5, p. 525-541, Sept./Oct. 2004. 
PALACIN, J. J. F. et al. Secagem combinada de café cereja descascado. Revista Engenharia na Agricultura, Viçosa, v. 17, n. 3, p. 244-258, May./ June. 2009.

RATTAN, S. etal.A comprehensive review on utilization of wastewater from coffee processing. Environmental Science And Pollution Research, Berlin Heidelberg, v. 22, n. 9, p. 6461-6472, May. 2015.

RESENDE, O. et al. Influência do tipo de pavimento na secagem de clones de café (Coffea canephora Pierre) em terreiros de concreto e chão batido. Revista Brasileira de Produtos Agroindustriais, Campina Grande, v. 9, n. 2, p. 171-178, July./Dec. 2007.

RIBEIRO, J. S. et al. Prediction of sensory properties of Brazilian Arabica roasted coffees by headspace solid phase microextraction-gas chromatography and partial least squares. Analytica Chimica Acta, v. 634, n. 2, p. 172-179, Feb. 2009.

SAATH, R. et al. Microscopia eletrônica de varredura do endosperma de café (Coffea arabica L.) durante o processo de secagem. Ciência e Agrotecnologia, Lavras, v. 34, n. 1, p. 196-203, Jan./Feb. 2010.
SANTOS, M. A.; CHALfOUN, S. M.; PIMENTA, C. J. Influência do processamento por via úmida e tipos de secagem sobre a composição, físico química e química do café (Coffea arabica L). Ciência e Agrotecnologia, Lavras, v. 33, n. 1, p. 213-218, Jan./Feb. 2009.

SIQUEIRA, V. C. et al. Drying kinetics of processed natural coffee with high moisture content. Coffee Science, Lavras, v. 12, n. 3, p. 400-409, July./Sept. 2017.

SONTAKKE, M. S.; SALVE, P. Solar drying technologies: A review. International Journal of Engineering Science, v. 4, n. 4, p. 29-35, Apr. 2015.

\section{SPECIALTY COFFEE ASSOCIATION OF} AMERICA. Backgrounder: what's special about specialty coffee? Long Beach, 2008. Available in: $<$ http://www.javadavescoffee.com/PDF_Documents/ Press-What-is-Specialty - Coffee.pdf $>$. Access in: 22 September 2017.

TAVEIRA, J. H. da S. et al. Potential markers of coffee genotypes grown in different Brazilian regions: A metabolomics approach. Food Research International, v. 61, p. 75-82, July. 2014. 